\title{
Rodziny polskiego pochodzenia mieszkające w Austrii - trudności i korzyści życia na pograniczu kultur. Studium indywidualnych przypadków
}

Streszczenie: Pogranicze, rozumiane jako miejsce spotkania kultur, z jednej strony może przynosić wiele korzyści dla życia i rozwoju jednostki, z drugiej, być przyczyną problemów i dylematów. W artykule wykorzystano koncepcję edukacji międzykulturowej w ujęciu Jerzego Nikitorowicza, a w badaniach posłużono się metodą indywidualnych przypadków. Materiał empiryczny stanowiący podstawę prowadzonych rozważań został zebrany za pomocą autorskich kwestionariuszy wywiadów oraz analizy dokumentów. Wyniki badań opisują trudności, jakie w kraju przyjmującym napotkali rodzice i ich dzieci, oraz korzyści i zalety, jakie dostrzegają, żyjąc poza granicami ojczyzny.

Słowa kluczowe: pogranicze kultur, wielokulturowość, rodziny polskiego pochodzenia, edukacja międzykulturowa, studium przypadku

\section{Wstęp}

Badania dotyczące edukacji międzykulturowej, różnorodności kulturowej, tożsamości, stereotypów czy problemów społeczeństw wielokulturowych posiadają już bogatą tradycję i są tematem podejmowanym przez licznych autorów (m.in. prace: Lewowicki, Ogrodzka-Mazur i Szczurek-Boruta, 2000; Lewowicki i Ogrodzka-Mazur, 2001; Iglicka, 2003; Błuszkowski, 2005; Nikitorowicz, Misiejuk i Sobecki, 2005; Nikitorowicz, 2001, 2009; Lewowicki, Ogniwjuk, Ogrodzka-Maur i Sysojewa, 2014; Królikowska, 2012; Kożyczkowska i Kossak-Główczewski 2014). Współczesne życie społeczne nacechowane jest różnorodnością. Dotyczy ona nie tylko kwestii zróżnicowania narodowego i etnicznego, ale również poglądów, prezentowanych systemów wartości, wzorów życia, statusu materialnego, religii, przekonań, języka. Szansą na zrozumienie tej różnorodności, otwarcie się na nią, kształtowanie tolerancji 
i szacunku, staje się życie w obszarze „pogranicza”. Tadeusz Lewowicki (2002, s. 29), odwołując się do ujęcia Michaiła Bachtina, wyróżnia „pogranicza kultur, religii czy wyznań, państw, narodów, grup etnicznych (...) pogranicza między tym, co globalne i lokalne, globalne i narodowe, uniwersalne i swoiste (...) pogranicza między światami ludzi bogatych i biednych, wykształconych i nie mających wykształcenia, żyjących w centrum i na peryferiach - i wiele innych". Na potrzeby niniejszego artykułu przyjęto szerokie rozumienie pogranicza rozumianego jako „miejsca spotkań kultur” (Mamzer, 2002, s. 137).

Życie w obszarze pogranicza może być szansą na rozwój jednostki, ale z drugiej strony - stanowić ryzyko dla kształtowania się jej tożsamości. „Z jednej strony wyzwala poczucie tożsamości społecznej i kulturowej (rodzinnej, religijnej, wyznaniowej, etnicznej), z drugiej zaś powoduje zagrożenie, utratę poczucia bezpieczeństwa, lęk przed nietolerancją grupy dominującej" (Nikitorowicz, 2001, s. 19). Kontakt z innością stwarza szansę na kształtowanie pozytywnych postaw względem drugiego człowieka, naukę o innych, ale również o samym sobie, dostrzeganie społeczeństwa zróżnicowanego, którego członkowie w niektórych aspektach są do siebie podobni, a w innych całkiem odmienni. Jerzy Nikitorowicz (2001, s. 18), powołując się na Floriana Znanieckiego, zwraca uwagę, iż „twórczy rozwój ludzkości wymaga, aby człowiek uczestniczył aktywnie co najmniej w dwu kulturach, doceniając obie. W takim przypadku ma miejsce możliwość czerpania więcej niż z jednego źródła, przyswajania i konstruowania dwoistego systemu tożsamości”.

\section{Wyniki badań własnych}

W pracy przyjęto perspektywę międzykulturowości w opracowaniu Nikitorowicza (2009, s. 282), której rezultatem ma być „dynamizacja społeczno-kulturowa różnych grup, wzajemne poznanie, zbliżenie i integracja, z zachowaniem własnej odrębności i własnych wizji rozwoju" oraz paradygmat „»Współistnienia «, dialogu i negocjacji, akcentując równorzędność kultur, transkulturowość potrzeb, dążeń i aspiracji ludzkich" (Nikitorowicz, 2012, ss. 268-269).

Grupę badaną stanowiły rodziny polskiego pochodzenia mieszkające od kilku lat w Austrii. Łącznie przebadano sześć osób dorosłych (rodziców dzieci, małżeństw w wieku 30-35 lat) oraz pięcioro dzieci ${ }^{1}$. W badaniach wyko-

1 W badaniach wzięły udział trzy dziewczynki w wieku 7 lat, 8 lat i 10 lat oraz dwóch chłopców w wieku 7 lat i 9 lat. 
rzystano metodę indywidualnych przypadków (Łobocki, 2010, ss. 253-254). Materiał empiryczny zebrano za pomocą autorskich kwestionariuszy wywiadów (dla rodziców i dla dzieci) oraz treściowej analizy dokumentów (zeszytów dzieci, opinii przedszkolnej, informacji o rozpoczęciu roku szkolnego, świadectw ukończenia klasy). W analizie wywiadów zastosowano redukcję danych - kodowanie (Rubacha 2008, ss. 261-268). Dobór badanej grupy miał charakter celowy.

Głównym celem badań było poznanie opinii rodziców i dzieci na temat trudności i korzyści życia w obszarze pogranicza - na terytorium Austrii, jako członków grupy mniejszościowej. Badania przeprowadzone zostały w lipcu i sierpniu 2018 roku w powiecie Sankt Pölten-Land.

Motyw wyjazdu wszystkich badanych rodzin związany był z chęcią poprawy sytuacji materialnej, poprawy jakości życia. W klasyfikacji migracji zarobkowej w ujęciu Wiolety Danilewicz (2010, ss. 193-194) wypowiedzi badanych zakwalifikować można jako „migrację przetrwania” - której główną przyczyną było zaspokojenie podstawowych potrzeb rodziny, oraz „migrację szansy", której główną przyczyną była chęć zaspokojenia indywidualnej potrzeby rodziny, jaką jest budowa domu:

Nie chcieliśmy zostać w Polsce, ponieważ tam przeważnie zarabia się najniższą krajową lub nieco powyżej. Miałem do wyboru pracować w Polsce i myśleć o tym jak żyć i wyżywić rodzinę, albo wyjechać i spróbować za granicą.

Szukałem dobrze płatnej pracy w kraju, ale nie znalazłem. W końcu kolega zaproponował mi wyjazd za granicę, bo on pracował tu wcześniej. Nie chciałem żyć w Polsce z myślą czy pieniędzy starczy nam do końca miesiąca. Wyjechałem, a po miesiącu przyjechała do mnie żona z dziećmi i zostali. Nie wyobrażaliśmy sobie żyć osobno w dwóch państwach.

Chcieliśmy wyjechać, żeby uzbierać pieniądze na budowę domu. W Austrii zarabia się lepiej niż w Polsce. Mamy tu dużo lepszą sytuację finansową niż w kraju. Wyjazd stanowił dla nas szansę, by zacząć tworzyć coś wspólnie od podstaw.

W wypowiedziach badanych wyróżnia się aspekt - szansy, nadziei na lepsze życie, pragnienie bezpieczeństwa finansowego. Względy ekonomiczne nie są jedynym wyznacznikiem powrotu rodzin do ojczyzny. Z upływem lat stały się nim również możliwości edukacyjne dzieci, które uczęszczają do szkoły w Austrii. Rodzice obawiają się, iż po powrocie do kraju dzieci będą miały trudności z opanowaniem ortografii, niezrozumieniem pojęć mate- 
matycznych czy nieznajomością historii Polski. Wskazują również na obawy dotyczące nawiązywania relacji z rówieśnikami i odrzucenia przez grupę rówieśniczą².

Dwie z rodzin początkowo planowały wyjazd na około 2 lata, a po tym czasie powrót do kraju, jednak do tej pory wciąż przebywają za granicą. Trzecia z rodzin nie planowała powrotu, licząc pobyt za granicą w latach, ale biorąc pod uwagę zmianę sytuacji materialnej, która pozwoliłaby im na powrót do ojczyzny i realizację zamierzonych planów związanych z budową domu. Jak słusznie zauważa Hanna Mamzer (2002, s. 133), wyjazd, którego motywem jest dążenie do poprawy sytuacji materialnej, „nie jest planowany jako opuszczenie kraju »na zawsze«, jednak odkładany termin powrotu powoduje powolne wrastanie w nową kulturę". Szczególnie widoczne jest ono w wypowiedziach dotyczących obchodzenia Świąt Wielkanocnych, Bożego Narodzenia, w których rodziny kultywują tradycje austriackie, oraz uczestnictwie w życiu społeczno-kulturalnym środowiska lokalnego.

Po przybyciu do Austrii największą trudność w relacjach międzyludzkich sprawiał badanym język:

Mój mąż potrafił mówić po niemiecku. Ja i dzieci nie. Kiedy szedł do pracy zostawaliśmy sami bez możliwości kontaktu z drugim człowiekiem. Dzieci szybko nauczyły się języka w przedszkolu. Mi nauka szła gorzej. Bałam się rozmawiać z ludźmi, żeby czegoś nie pomylić, a jak już chciałam mówić to brakowało mi niektórych słów. Z czasem się przełamałam i przestałam zwracać uwagę na to, czy mówię poprawnie. Zależało mi tylko na tym, żeby ktoś zrozumiał, o co mi chodzi.

Uczyłem się niemieckiego w liceum, ale kiedy przyjechałem do Austrii, okazało się, że ta nauka nie przygotowała mnie do komunikacji za granicą.

Największą trudnością był dla mnie brak znajomości języka. Najtrudniej wiedzieć, co chce się powiedzieć po polsku, ale nie potrafić tego przełożyć na język niemiecki.

Badane dzieci uczęszczały do placówki przedszkolnej w Austrii, choć nie jest to obowiązkowy etap przygotowawczy do nauki szkolnej ${ }^{3}$. Rodzice chcie-

2 Na temat dyskryminacji i nierównego traktowania dzieci powracających do kraju pisały: Szydłowska, P., Durlik, J., Grzymała-Moszczyńska, J. i Grzymała-Moszczyńska, H. 2017. (Nie)równe traktowanie dzieci powracających w polskiej szkole. Edukacja Międzykulturowa. 2 (7), ss. 200-224.

3 Na temat systemu edukacji w Austrii można przeczytać w pracach: Baran, Z. 1997. Przedszkola w Austrii. Wychowanie w Przedszkolu. 9, ss. 530-532; Dziewulak, D. 
li, aby w przedszkolu dzieci nauczyły się języka, wdrożyły się do przestrzegania zasad, nauczyły się współpracy, poznały rówieśników i zintegrowały z dziećmi.

Początkowo dzieci miały trudności z porozumiewaniem się z rówieśnikami i nauczycielem. Często starały się porozumiewać za pomocą gestów, wykonywały czynności, obserwując i naśladując ruchy i zachowanie rówieśników, niejednokrotnie nie brały udziału w zabawach, nie wiedząc, na czym polegają. Ten okres adaptacji rodzice opisują jako najcięższy i najtrudniejszy:

Najgorzej było na początku. Kiedy Filip miał iść do przedszkola, a nie rozumiał nic po niemiecku. Nie potrafił nic powiedzieć. Cieszył się, że idzie do dzieci, a tak naprawdę nie wiedział, co go tam czeka. A ja się bałam, że będzie się bawił sam, że zacznie płakać i nikt nie będzie wiedział czemu, że dzieci będą się z niego śmiały. A on wrócił z przedszkola uśmiechnięty.

Początki były bardzo ciężkie. Kiedyś przyszłam do przedszkola i zobaczyłam, że moja córka siedzi na ławce i płacze. Okazało się, że nie poszła na religię. To były zajęcia dodatkowe. Nauczycielka nie wiedziała, że jest na nie zapisana. Dzieci poszły, a ona nie potrafiła jeszcze powiedzieć Pani, że ona też ma iść. Została sama, a ja przyszłam po nią później, tak jak miała skończyć religię. Wtedy bardzo się wystraszyłam. Że jesteśmy w obcym miejscu, bez znajomości języka.

Po zakończeniu edukacji przedszkolnej dzieci otrzymały opinię od nauczycielki, w której zawarte były informacje dotyczące ich postępów, pracy w przedszkolu, integracji z rówieśnikami oraz życzenia dobrego startu w szkole. W jednej z opinii nauczycielka zwraca również uwagę na zachowanie dziecka wobec kolegi, któremu pomógł się ubrać, chwaląc jego postępowanie.

Opanowanie języka niemieckiego w mowie i piśmie, jak również jego rozumienie ze słuchu, przyczyniło się do zmniejszenia stresu związanego $\mathrm{z}$ edukacją szkolną. Rodzice zwracają również uwagę na dobry kontakt z nauczycielkami w szkole, które na bieżąco informowały o postępach dziecka, jak również obszarach, nad którymi dziecko powinno bardziej popracować. Obawy towarzyszyły rodzicom głównie przez pierwsze dni rozpoczęcia przez

1997. Systemy szkolne Unii Europejskiej. Warszawa: Wydawnictwo „Żak”; Igielska, B. 2004. Znad Modrego Dunaju. Głos Nauczycielski. 35, ss. 200-224; Kopik, A. 2004. Edukacja przedszkolna i wczesnoszkolna w krajach Unii Europejskiej. Nauczyciel i Szkoła. 3-4, ss. 20-36; Muszczyński, L. 2009. Naddunajski dualizm edukacyjny. Austriacki system edukacyjny. Dyrektor Szkoty. 1, ss. 36-39. 
dziecko edukacji szkolnej i związane były z przejściem do nowej, nieznanej dziecku placówki. Ułatwieniem zarówno dla rodziców, jak i dzieci były przekazywane co roku informacje na piśmie dotyczące rozpoczęcia roku szkolnego, odbywającego się z tej okazji nabożeństwa, czasu trwania zajęć w pierwszym tygodniu czy możliwości zapisu dziecka na „opiekę popołudniową”.

\title{
Ryc. 1. Opinia o dziecku kończącym edukację przedszkolną w Austrii
}

\section{Lieber Filip!}

Traismauer, Juni 2017

\begin{abstract}
Dein letztes Kindergartenjahr durfte ich Dich begleiten und unterstützen. Im September 2016 habe ich Dich kennen gelernt und mir ist gleich aufgefallen, dass Du schon viele Freunde im Kindergarten hast, die auf Dich gewartet haben und noch heute Deine Freundschaft sehr schätzen. Du hast Dich von Anfang an stets höflich, nett und freundlich mir und auch den Kindern gegenüber gezeigt. Du machst den Eindruck, dass du gerne in den Kindergarten gehst und dass Du Dich für viele Sachen sehr begeistern kannst. Wie ich beobachten konnte, hast Du im Laufe des letzten Kindergartenjahres sehr große Fortschritte gemacht. Du spielst und beschäftigst Dich mit Tisch- und Gesellschaftsspielen gleichermaßen gerne. Ebenso kannst Du Dich auch über einen längeren Zeitraum in den verschiedenen Spielecken beschäftigen. Dabei hast Du immer wieder tolle Spielideen. Ebenso zeigst Du Interesse in unseren Sitzkreisen und bist stets aufmerksam. Du beteiligst Dich an Gesprächen und machst bei Liedern, Spielen... gerne mit.

Wenn Du Dich mal ablenken lässt, dann ist dies meist nur von kurzer Dauer. Du findest immer wieder schnell zum Thema zurück.

Auf meine Fragen kannst du passend antworten und Aufgaben, die ich Dir stelle kannst Du gut umsetzen. Auf Dich kann man sich verlassen. Wenn jemand Hilfe benötigt bist Du zur Stelle. Den jüngeren gegenüber bist Du sehr hilfsbereit. So habe ich Dich dabei beobachtet, wie Du Emir beim Anziehen geholfen hast, ohne dass ich Dich dazu aufgefordert habe. Das war sehr schön von Dir.

Du kennst unsere Gruppenregeln und Du hältst Dich daran. Wenn Du einmal Hilfe oder Unterstützung brauchst, weißt Du, dass Du zu uns kommen kannst und Du fragst höflich nach.
\end{abstract}

Besonders hervor heben möchte ich Dein Verhalten während der Lernwerkstatt. Hier hast Du Dich von Anfang an sehr gewissenhaft und selbständig gezeigt. Und von mal zu mal hast Du Dich noch mehr gesteigert und große Freude bei den verschiedenen Stationen gezeigt. Du hast keine Probleme die gesamte Aufgabenstellung zu erfassen und wie gewünscht umzusetzen. Dabei zeigst Du Dich sehr geschickt. Du arbeitest zügig und sehr ordentlich dabei.

Besondere Freude machen Dir die Bewegungseinheiten im Turnsaal. Du turnst sehr gerne und man sieht dabei, dass Du schon eindeutig zu den größeren gehörst. Sich mit anderen messen macht Dir besonders Spaß, dabei bist Du aber auch nicht zu sehr enttäuscht, wenn mal ein anderer besser ist wie Du.

Auch im Garten hast Du viel Freude. Vor allem mit den gleichaltrigen Buben aus der Gruppe hast Du besonders viel Spaß.

Lieber Filip, ich wünsche Dir für Deinen weiteren Lebensweg alles erdenklich Liebe und Gute.

Vor allem wünsche ich Dir einen guten Start in der Schule und viele, neue Freunde.

Mögest Du stets liebe Menschen um Dich haben, die Dich begleiten und unterstützen. Bleib weiterhin ein so fröhlicher Bub, der so viel Freude und Interesse an Neuem hat.

Deine Kindergartenpädagogin

Źródło: badania własne. 
Ryc. 2. Informacja dla rodziców dotycząca rozpoczęcia roku szkolnego Schulbeginn 2018/19

Die Schule beginnt am Montag, 3. September 2018. Ab 7.30 Uhr ist die Schule geöffnet. Die Schülerinnen und Schüler gehen in ihre Klassen. Die 1. Klassen sind im 1.Stock.

Um 8.00 Uhr gehen die Schülerinnen und Schüler, die den Wortgottesdienst besuchen mit ihren Lehrerinnen in die Stadtpfarrkirche. Alle anderen Schülerinnen und Schüler bleiben in der Schule.

Um 9.30 Uhr werden die Kinder am ersten Schultag entlassen. (Ihr Kind wird bis $11.30 \mathrm{Uhr}$ beaufsichtigt, sollte es am ersten Tag die Nachmittagsbetreuung besuchen).

Die Nachmittagsbetreuung beginnt mit 03.09.2018.

Am Dienstag, Mittwoch, Donnerstag und Freitag (1. Schulwoche) endet der Unterricht

- für die Vorschulgruppe um $10.35 \mathrm{Uhr}$

- für die 1.Klassen, 2. Klassen, 3. Klassen und 4. Klassen um 11.30 Uhr.

Der Elternabend für die Schulanfänger findet am Mittwoch, 5.9.2018 um 19.00 Uhr in der Klasse Ihres Kindes statt.

Der Elternabend für die Nachmittagsbetreuung ist ebenfalls am Mittwoch, 5.9.2018 bereits um 18.00 Uhr in den Räumen der Nachmittagsbetreuung vorgesehen.

\section{Unterrichtsende 2. Schulwoche:}

Vorschulgruppe, 1. Klassen und 2. Klassen - immer 11.30 Uhr

3. Klassen und 4. Klassen - Mittwoch $12.30 \mathrm{Uhr}$ - sonst 11.30Uhr

Mit freundlichen Grüßen

Źródło: badania własne.

Rodzice chwalą austriacki system edukacji szkolnej, uważając, że dzieci bardziej niż w Polsce uczone są wiedzy praktycznej, która będzie przydatna w przyszłości, a przekazywanie gotowej wiedzy, którą uczniowie mają przyswoić, nie jest główną metodą nauczania. Jako jedną z różnic zaznaczają również metodę nauki pisania. W klasie pierwszej, aby nauczyć się pisać starannie, dzieci pisały w zeszycie wyłącznie wielkimi literami.

Ryc. 3. Przykładowa strona z zeszytu ucznia klasy 2

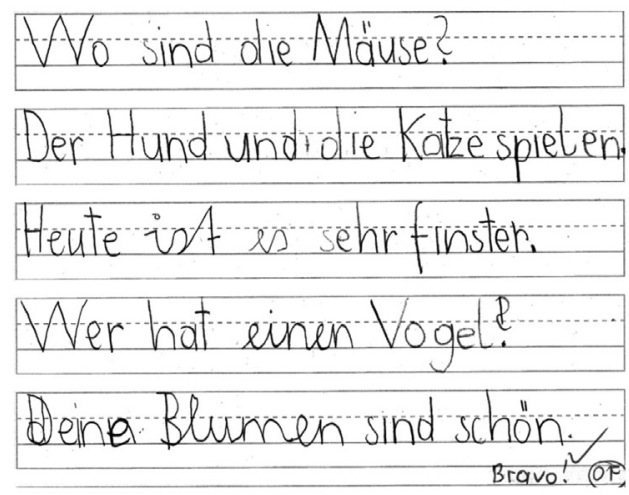

Źródło: badania własne. 
Zarówno dla rodziców, jak i dla dzieci największą trudność związaną z życiem poza granicami ojczyzny stanowiło porozumiewanie się w języku obcym. Po opanowaniu języka niemieckiego rodzice zauważyli znaczną poprawę w aktywnym życiu społecznym i kulturalnym, częściej sami rozpoczynali konwersację z sąsiadami, wyjeżdżali na organizowane spotkania i imprezy. Początkowo zamknięci we własnym środowisku rodzinnym, stali się otwartymi i aktywnymi członkami społeczności lokalnej. Dla dzieci porozumiewanie się w języku polskim i niemieckim nadal stanowi problem. Zdaniem rodziców dzieci coraz lepiej mówią w języku niemieckim, a coraz więcej słów brakuje im w rozmowach po polsku. Często zdarzają się sytuacje, w których rozpoczynają zdanie w języku ojczystym i wplatają słowa z języka niemieckiego lub podczas rozmów w języku polskim, nie rozumiejąc danych zwrotów, pytają: „co to jest...?”, "co to znaczy...?".

Rodzice zwracają uwagę, że dla nich najważniejsze jest zrozumienie wypowiedzi i udzielenie odpowiedzi tak, by zostali zrozumiani, choć często są przekonani, że użyli słowa w niewłaściwej kolejności lub niewłaściwej odmianie. Inaczej jest w przypadku dzieci. Nauka języka obcego w przedszkolu i dalsze jej doskonalenie w szkole, a przede wszystkim słuchanie wypowiedzi rówieśników, z którymi podczas pobytu w placówce porozumiewają się w języku obcym, sprawiła, że dzieci bardzo dużą uwagę zwracają na akcent i poprawną wymowę, niejednokrotnie poprawiając wypowiedzi swoich rodziców. Jedno z badanych dzieci, śmiejąc się, wspomina sytuację w szkole, podczas której źle wypowiedziało słowo i tłumaczyło rówieśnikom, że powiedziało je w języku polskim:

Kiedyś w szkole się śmiali. Bo powiedziałem „halo”. A przecież mówi się „hallo”. A ja powiedziałem do nich po polsku.

Przebywając w Polsce, odwiedzając rodzinę w kraju ojczystym, dzieci niejednokrotnie wypowiadają zdania w języku niemieckim, szczególnie podczas zabaw z rodzeństwem lub samotnych. Nieświadome komunikowanie się w języku obcym ma również miejsce w czasie różnych sytuacji, m.in. podczas wycieczek w Polsce:

Kiedyś w Polsce babcia zabrała dzieci do wesołego miasteczka. Poszli na karuzelę, Filip się wystraszył i zaczął krzyczeć: „O mein Gott! O mein Gott!"

Rodzice zwracają uwagę, że początkowo, gdy dzieci były mniejsze, podczas powrotów do kraju nie potrafiły zrozumieć i dziwiły się, że w Polsce wszyscy mówią w języku polskim: 
Jak przyjeżdżaliśmy do polski i szliśmy na plac zabaw, to Marysia pytała dzieci: „a ty mówisz po polsku?”

Kilka razy syn mnie zapytał: „mamo, a w Polsce mówi się po polsku?", albo był zdziwiony, gdy jakaś dziewczynka coś do niego powiedziała i podbiegał do mnie i mówił po cichu: „ona mówi po polsku”. Wtedy mu odpowiadałam: „bo jesteśmy w Polsce”. Jak był mniejszy, to nie potrafił tego zrozumieć.

W ciekawy sposób rodzice definiują „dom”. Jako miejsce codziennego życia w Austrii, przestrzeń, mieszkanie, budowlę. Dla wszystkich jednak „dom rodzinny" to nie miejsce w Austrii, w którym żyją, ale miejsce, do którego zawsze mogą wrócić w kraju ojczystym, miejsce, w którym się urodzili, za którym odczuwają tęsknotę. Zauważają jednak, że z upływem lat stali się członkami społeczności lokalnej, tradycje i zwyczaje austriackie zaczęły przenikać ich życie i przeplatać się z polskimi:

Wydaje mi się, że żyjemy już w dwóch kulturach. Z każdej coś bierzemy, bo żadna nie jest gorsza ani lepsza. Obchodzimy różne święta w Austrii i w Polsce, śpiewamy kolędy po niemiecku i po polsku, jemy potrawy polskie i austriackie.

Życie w Austrii jest ciekawe. Nauczyliśmy się panujących zwyczajów. Staramy się je obchodzić, ale pamiętamy też o tym, co wynieśliśmy z domu rodzinnego, więc nasza kultura jest urozmaicona. Nawet na Dzień Matki dzieci składają mi życzenia w Austrii w drugą niedzielę maja, bo tak jest ten dzień tutaj obchodzony, a ja dzwonię do Polski 26 maja i składam życzenia swojej mamie.

Zdaniem wszystkich rodziców Austriacy to bardzo otwarty i miły naród. Niejednokrotnie podczas wywiadów podkreślali, że w wielu sytuacjach mogli liczyć na pomoc sąsiadów i znajomych, których poznali w Austrii. Interesujące jest zdanie dwójki badanych, którzy uważają, że pozytywny stosunek starszych osób wobec Polaków wynika nie tylko z chęci pomocy, ale również ze świadomości losów historycznych obydwóch krajów. Niejednokrotnie na słowa, że są Polakami, słyszeli odpowiedzi: „a my w przeszłości zrobiliśmy wam tyle złego".

W opinii rodziców życie w Austrii przynosi przede wszystkim korzyści materialne. Wśród zalet dostrzegają oni również naukę języka, poznanie innej kultury, tradycji, poznanie historii kraju, zwiedzanie pięknych miejsc, zdobycie nowych doświadczeń, zwiększenie samodzielności, niezależności, radzenia sobie w ciężkich sytuacjach. Zdaniem badanych różnice kulturowe sprzyjają kształtowaniu postaw tolerancji i otwartości, a Polska jest krajem 
mniej tolerancyjnym i bardziej zamkniętym na różnorodność. W społeczeństwie austriackim cenią natomiast poszanowanie dla odmiennych kultur i ich równość.

Życie w środowisku zróżnicowanym kulturowo wiąże się z przejawianiem określonych zachowań względem kultury mniejszościowej i kultury dominującej. Charakterystyczną cechą badanych rodzin jest silna identyfikacja z dwiema kulturami, określająca „człowieka pogranicza” ${ }^{4}$. Badani biorą aktywny udział w życiu społecznym i kulturowym społeczności dominującej, kultywując jednocześnie kulturę rodzimą. Dążą oni do poznania i integracji z kulturą w kraju przyjmującym, co stanowi element założeń edukacji międzykulturowej, mając jednocześnie świadomość własnej odrębności, tęsknoty za ojczyzną. Potwierdza się stanowisko Pawła Boskiego (2010, s. 548), iż „przebywając przez czas dłuższy lub na stałe w obszarze oddziaływania kultury odmiennej od macierzystej, człowiek staje się w jakimś stopniu dwukulturowy".

\section{Konkluzje}

Wioletta Danilewicz (2008, s. 288) zwraca uwagę, iż migracja jest jedną z możliwości życia w ponowoczesnym świecie. „Niektórzy korzystają z niej w myśl hic et nunc: jeśli mogę spróbować, dlaczego tego nie zrobić. Inni traktują ją w kategoriach szansy, jeszcze inni podejmują ryzyko. Wszyscy kształtują własną biografię, poszukując własnego miejsca”. Wyjazd całej rodziny za granicę nie osłabia więzi rodzinnych, jak być może w przypadku wyjazdu jednego z członków ${ }^{5}$. Rodzina staje za to w obliczu innych trudności, wśród

4 J. Nikitrowicz wyróżnia 4 typy tożsamości kulturowej. Nikitorowicz, J. 2001. Pogranicze, tożsamość, edukacja międzykulturowa. Białystok: Wydawnictwo Uniwersyteckie „Trans Humana”, s. 86.

$5 \mathrm{Na}$ temat trudności, funkcjonowania rodziny, relacji małżeńskich podczas migracji jednego z małżonków można przeczytać między innymi w pracach: Becker-Pestka, D. 2012. Rodzina w obliczu migracji zarobkowej. Colloquium Wydziatu Nauk Humanistycznych i Społecznych AMW. 1, ss. 9-26; Danilewicz, W. 2010. Rodzina ponad granicami. Transnarodowe doświadczenia wspólnoty rodzinnej. Białystok: Wydawnictwo Akadrmickie "Trans Humana”; Gagat-Matuła, A. i Smalej, O. 2014. Komunikacja w małżeństwach doświadczających rozłąki migracyjnej. W: Nikitorowicz, J., Muszyńska, J. i Boćwińska-Kiluk, B. red. Od wielokulturowości miejsca do międzykulturowości relacji społecznych. Wspótczesne strategie kreowania przestrzeni życia jednostki. Warszawa: Wydawnictwo Akademickie „Żak”; Tarka, K. 2014. Sytuacja 
których edukacja dzieci zajmuje pierwsze miejsce. Rodzice nie tylko obawiają się trudności w związku z podjęciem nowej pracy w obcym miejscu, ale przeżywają stres związany z adaptacją, integracją i edukacją swoich dzieci.

Życie w innej, obcej kulturze stwarza więcej okazji do kształtowania otwartości na innych i wyjścia poza własną kulturę niż środowisko jednorodne kulturowo. Zamknięcie się na odmienność, separacja i etnocentryzm nie sprzyjają sytuacjom wchodzenia w interakcje i wymiany doświadczeń. W sytuacji przebywania na stałe lub tymczasowo w odmiennym kulturowo środowisku warto dostrzec w niej wartość i szansę na rozwój. Na interesujący aspekt rozwoju w środowisku zróżnicowanym kulturowo zwraca uwagę Alina Szczurek-Boruta (2001, s. 134), zdaniem której „człowiek podlegający procesom socjalizacji i wychowania w warunkach wielokulturowości jest relatywnie lepiej przygotowany do kontaktu z innymi, komunikacji międzykulturowej w porównaniu z mieszkańcami środowisk monokulturowych". Grupy mniejszościowe poprzez życie na pograniczu mają lepszą okazję do zdobycia wiedzy kulturowej na temat grupy dominującej, ale również do nabycia kluczowych kompetencji w zakresie porozumiewania się w języku obcym. Badani niejednokrotnie zwracali uwagę na życie w obszarze pogranicza, jako miejsca dającego wiele możliwości własnego rozwoju, ale również własnego poznania, kształtowania pozytywnych postaw, szacunku do drugiego człowieka, dla odmienności i różnorodności.

Należy jednak zwrócić uwagę, że rozpoczęcie edukacji w szkole za granicą to ciężki okres dla dziecka, które nie porozumiewa się w języku obcym, a sytuacja stresu może się powtórzyć po raz kolejny, kiedy dziecko wraca do kraju i kontynuuje naukę w Polsce. Różnice w programie nauczania, zasobie zdobytych wiadomości, a przede wszystkim braki językowe, przyczynić się mogą do niepowodzeń edukacyjnych, wycofania w kontaktach z rówieśnikami, a dla rodziców być powodem do niepokoju i obawy o dalsze kształcenie swoich dzieci.

Rodziny mieszkające w obszarze pogranicza rozumianego jako miejsce spotkania kultur napotykają na swej drodze wiele trudności, szczególnie związanych z procesem komunikowania się, ale zarazem otrzymują szanse, jakich nie dostarcza środowisko monokulturowe - poznania, zrozumienia, życia w środowisku różnorodnym, z którego czerpać można wiele korzyści dla własnego rozwoju.

Z punktu widzenia badań dotyczących tematyki wielokulturowej ciekawym kierunkiem byłoby przeprowadzenie prac badawczych po zakończeniu 
edukacji dzieci w Austrii i ich dalszych planów życiowych, edukacyjnych i dylematów tożsamościowych lub - w sytuacji powrotu do ojczyzny badań w obszarze kontynuowania edukacji w polskiej szkole, trudności, różnic w zakresie posiadanej wiedzy i umiejętności czy integracji z rówieśnikami.

\section{Bibliografia}

Baran, Z. 1997. Przedszkola w Austrii. Wychowanie w Przedszkolu. 9, ss. 530-532 .

Becker-Pestka, D. 2012. Rodzina w obliczu migracji zarobkowej. Colloquium Wydziału Nauk Humanistycznych $i$ Społecznych AMW. 1, ss. 9-26.

Błuszkowski, J. 2005. Stereotypy a tożsamość narodowa. Warszawa: Dom Wydawniczy ELIPSA.

Boski, P. 2010. Kulturowe ramy zachowań społecznych. Podręcznik psychologii międzykulturowej. Warszawa: PWN.

Danilewicz, W. 2008. Wybrane uwarunkowania migracji zagranicznej młodych Polaków. W: Lalak, D. red. Dom i ojczyzna. Dylematy wielokulturowości. Warszawa: Uniwersytet Warszawski, Instytut Praktyki Społecznej i Resocjalizacji, Międzykulturowe Centrum Adaptacji Zawodowej, ss. 279-289.

Danilewicz, W. 2010. Rodzina ponad granicami. Transnarodowe doświadczenia wspólnoty rodzinnej. Białystok: Wydawnictwo „Trans Humana”.

Dziewulak, D. 1997. Systemy szkolne Unii Europejskiej. Warszawa: Wydawnictwo Akademickie „Żak”.

Gagat-Matuła, A. i Smalej, O. 2014. Komunikacja w małżeństwach doświadczających rozłąki migracyjnej. W: Nikitorowicz, J., Muszyńska, J. i Boćwińska-Kiluk, B. red. Od wielokulturowości miejsca do międzykulturowości relacji społecznych. Wspótczesne strategie kreowania przestrzeni życia jednostki. Warszawa: Wydawnictwo Akademickie „Żak”, ss. 199-210.

Igielska, B. 2004. Znad Modrego Dunaju. Gtos Nauczycielski. 35, ss. 8-9.

Iglicka, K. 2003. Integracja czy dyskryminacja. Polskie wyzwania i dylematy u progu wielokulturowości. Warszawa: Wydawnictwo Fundacja Instytutu Spraw Publicznych.

Kopik, A. 2004. Edukacja przedszkolna i wczesnoszkolna w krajach Unii Europejskiej. Nauczyciel i Szkoła. 3-4, ss. 20-36.

Kożyczkowska, A. i Kossak-Główczewski, K. red. 2014. Mniejszości etniczne. Dylematy i konteksty tożsamościowe. Gdańsk: UG. 
Królikowska, K. red. 2012. (Złudne) obietnice wielokulturowości. Warszawa: UW.

Lewowicki, T., Ogrodzka-Mazur, E. i Szczurek-Boruta, A. red. 2000. Edukacja międzykulturowa w Polsce i na świecie. Katowice: UŚ.

Lewowicki, T. i Ogrodzka-Mazur E. red. 2001. W poszukiwaniu teorii przydatnych w badaniach międzykulturowych. Cieszyn: UŚ - Filia w Cieszynie.

Lewowicki, T. 2002. W poszukiwaniu modelu edukacji międzykulturowej. W: Lewowicki, T., Nikitorowicz, J., Pilch, T. i Tomiuk, S. red. Edukacja wobec tadu globalnego. Warszawa: Wydawnictwo Akademickie „Żak”, ss. 15-32.

Lewowicki T., Ogniwjuk, W., Ogrodzka-Maur, E. i Sysojewa, S. red. 2014. Wielokulturowość i edukacja. Warszawa: Wyższa Szkoła Pedagogiczna ZNP.

Łobocki, M. 2010. Wprowadzenie do metodologii badań pedagogicznych. Kraków: Oficyna Wydawnicza „Impuls”.

Mamzer, H. 2002. Tożsamość w podróży. Wielokulturowość a kształtowanie tożsamości jednostki. Poznań: UAM.

Muszczyński, L. 2009. Naddunajski dualizm edukacyjny. Austriacki system edukacyjny. Dyrektor Szkoty. 1, ss. 36-39.

Nikitorowicz, J. 2001. Pogranicze, tożsamość, edukacja międzykulturowa. Białystok: Wydawnictwo Uniwersyteckie „Trans Humana”.

Nikitorowicz, J., Misiejuk D. i Sobecki, M. red. 2005. Region, tożsamość, edukacja. Białystok: Wydawnictwo Uniwersyteckie „Trans Humana”.

Nikitorowicz, J. 2009. Edukacja regionalna i międzykulturowa. Warszawa: WAiP.

Nikitorowicz, J. 2012. Wielokulturowość wschodniego pogranicza Polski w przeszłości i współcześnie. W: Królikowska, J. red. (Złudne) obietnice wielokulturowości. Warszawa: UW, ss. 267-291.

Rubacha, K. 2008. Metodologia badań nad edukacją. Warszawa: WAiP.

Szczurek-Boruta, A. 2001. Wybrane wyznaczniki komunikacji międzykulturowej. W: Nikitorowicz, J., Sobecki, M. i Misiejuk, D. red. Kultury tradycyjne a kultura globalna. Konteksty edukacji międzykulturowej. Tom I. Białystok: Wydawnictwo Uniwersyteckie „Trans Humana”, ss. 125-134.

Szydłowska, P., Durlik, J., Grzymała-Moszczyńska, J. i Grzymała-Moszczyńska, H. 2017. (Nie)równe traktowanie dzieci powracających w polskiej szkole. Edukacja Międzykulturowa. 2 (7), ss. 200-224.

Tarka, K. 2014. Sytuacja dziecka w rodzinie migracyjnej. Studia i Prace Pedagogiczne. 1, ss. 169-180. 


\title{
Families of the Polish origin living in Austria - the difficulties and benefits of the life on cultural borderlands. Case studies
}

\begin{abstract}
The verge, understood as a place where two cultures meet, may on the one hand bring a lot of benefits for the life and development of an individual; on the other hand it can cause plenty of problems and dilemmas. In the following work the conception of multicultural education created by Jerzy Nikitorowicz has been used, and the examinations have been based on the method of individual cases. The empirical material being the basis of the dissertation has been collected by original questionnaires, interviews and analysis of the documents. The results of the examinations describe struggles of parents and their children in the "receiving" country as well as benefits and good points which they notice in the fact of living outside Poland.
\end{abstract}

Keywords: cultural borderlands, multiculturalism, families of Polish origin, intercultural education, case study 